\section{Middle Crefaceous sediments from the eastern part of Walvis Ridge}

- The Walvis Ridge is one of the most conspicuous features of the South Atlantic. It extends from near Tristan da Cunha on the Mid-Atlantic Ridge to the African continental margin and has three main segments. The western scgment is oriented SW-NE, the central one N-S and the eastern one SSW-NNF. The Walvis Ridge may have kept pace with the opening of the South Atlantic which started in the Early Cretaceous ${ }^{1-6}$, either by transform fault mechanisms ${ }^{7,8}$ or by a mantle hot spot and plume ${ }^{9-12}$. The eastern segment is thought to have been built throughout the Middle Cretaceous, that is, between $120 \mathrm{~m} . \mathrm{y}$. ago and $80 \mathrm{~m} . \mathrm{y}$. ago ${ }^{13-15}$. We report information obtained from an investigation of the age and depositional conditions of sedimentary rock recovered during the Walda cruise of the RV Jean Charcot (AprilAugust 1971). -

White chalk fragments containing numerous fossils were recovered from a depth of $2,700 \mathrm{~m}$ by a dredge $(\mathrm{CH} 18 \mathrm{DR}$ 04 ) on the northern flank of the Walvis Ridge in the centre of the eastern segment $\left(19^{\circ} 33^{\prime} \mathrm{S}: 09^{\circ} 01^{\prime} \mathrm{E}\right)$ (Fig. 1). Smear slides of the calcareous matrix show mainly coccoliths and micritic calcite. Glaucophane and biotite are also present. The most abundant macrofossils are gastropods, remains of echinoderms (regular and irregular urchins: Holasteroida Spatangoida) and bivalves (including Ostreidac, Arcacea, Heterodonta and Neithea). One specimen of Neithea could be Neithea cf. shawi Pervinquière ( $=N$. coquandi Péron). The distribution of $N$. shawi is Albian-Cenomanian in the Angola Basin but mostly Cenomanian in northern Africa ${ }^{\mathbf{1 6}}$ This specimen is, however, poorly preserved and could belong to the species $N$. regularis Schlotheim. In Europe the distribution of $N$. regularis Schlotheim ranges from Turonian to Senonian (Freinex, personal communication). Thus the macro-

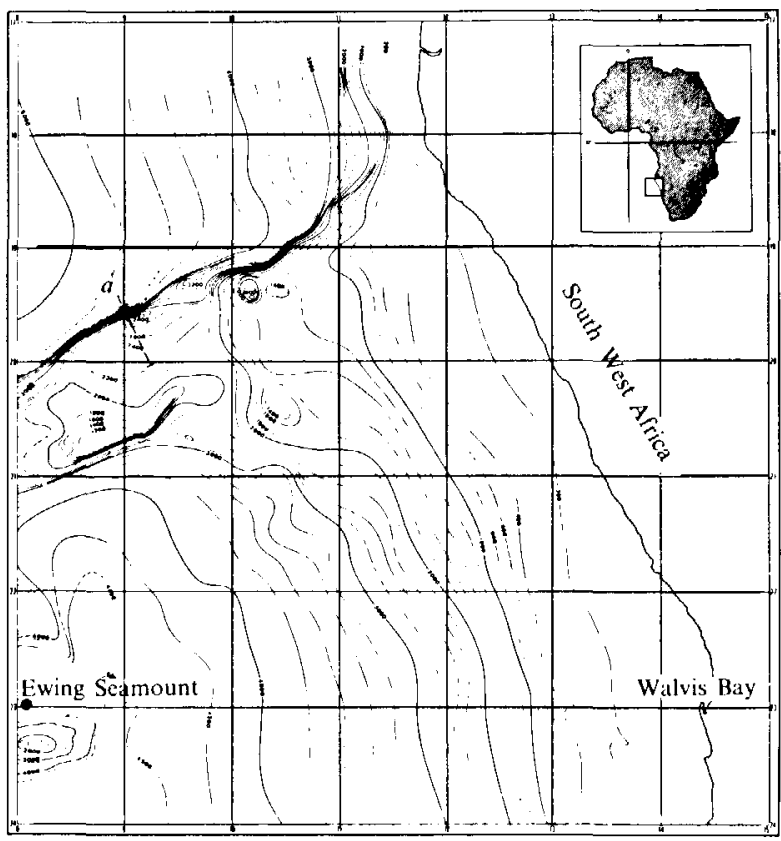

Fir. 1 Bathymetric map of the eastern segment of the Walvis Ridge showing the location of the seismic reflection profile shown in Fig. 2, and the locations of the sediment samples. $a$, Site of dredge. Depths in corrected metres. Contours at intervals of $200 \mathrm{~m}$.

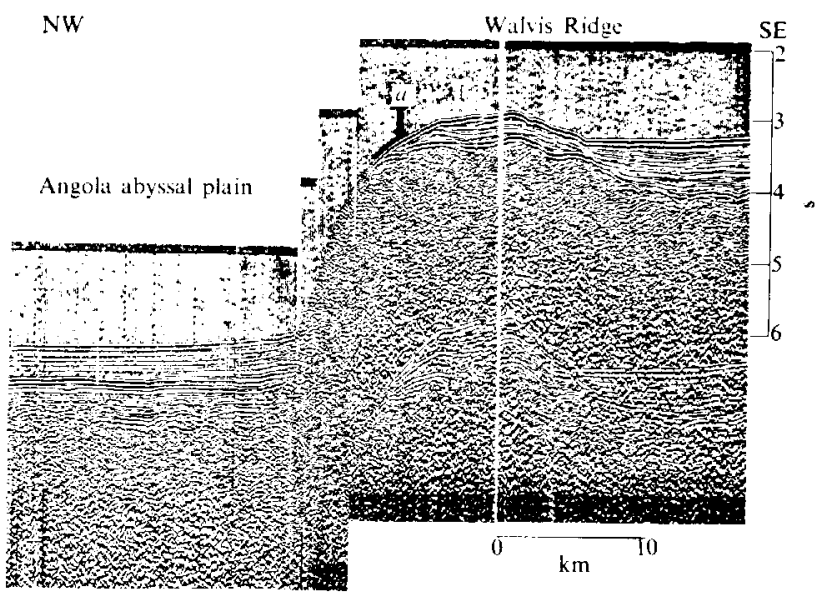

Fic. 2 Seismic reflection profile across the northern scarp of the castern segment of Walvis Ridge and location of the dredged rocks. $a$, Site of dredge.

fossils indicate an Albian-Senonian age. The nannofossils consist mainly of Lithastrinus floralis Stradner. Cricolithus multiradiatus Kamptner, C. pemmatoideus Deflandre, Loxolithus armilla (Black) and Parhabdolithus embergeri (Noël). These are typical Albian-Cenomanian species. The sediment is therefore tentatively dated Middle Cretaceous, that is, about 100 m.y.BP. This agrees with ages proposed by other authors ${ }^{13-15}$.

Macrofossils are not common in a coccolith ooze. Hypotheses for a depositional environment of the sediments, which might explain the observed association include (1) the coccoliths accumulated in deep water and the macrofossils are thanatococnoses transported from shallow depths by turbidity currents or some other process: (2) both the coccoliths and macrofossils were deposited in shallow water. We favour the second hypothesis, tentatively rejecting a mixed origin for the sediments because of the distance from the African coast and the absence of local seamounts. A shallow water environment would comply with the ecological needs of the macrofossils. Neithe a, for example, is commonly found in shallow water Albo-Cenomanian deposits in the Angola Basin $^{16}$. Furthermore, corcoliths are epipelagic organisms and cannot be used as precise depth indicators ${ }^{17}$. Although they are typical of open sea sedimentation, their occurrence does not necessarily imply deep water.

If the second hypothesis is correct, $100 \mathrm{~m} . \mathrm{y}$. ago the eastern segment of the Walvis Ridge would have been situated in an elevated position. Subsidence would have occurred probably by the late Cenomanian as seems to have been the case for several basins of the continental margin of West $A$ frica ${ }^{18}$. The total subsidence is estimated to be about $2.5 \mathrm{~km}$. The rate of subsidence is $25 \mathrm{~m}$ every million years, which is in good agrecment with rates estimated by Fox et al. ${ }^{19}$ If our calculations are correct, this rate is similar to that of a portion of cooling lithosphere of similar age and situated at the same distance from a mid-oceanic ridge ${ }^{20}$.

The results presented here suggest that the subsidence of the eastern segment of the Walvis Ridge occurred after Albian-Cenomanian time (100 m.y.Br).

We thank the scientific party and the crew of RV Jean Charcot during Walda cruise for their help. We acknowledge Mme Freinex, M. Brebion, M. Roman from the Museum National d'Histoire Naturelle and M. Deres from Société Nationale des Pétroles d'Aquitaine for advice concerning fossil 
identifications. Helpful discussions were held with J. M. Auzende, X. Le Pichon, H. D. Needham and G. Pautot.

Centre Océanologique de Bretagne,

L. Pastouret

$B P 397$

29279 Brest, France

Institut de Physique de Globe,

J. Gosuin

4, Avenue de Neptune,

94100 St-Maur-des-Fosses, France

Received January 16, 1974.

${ }^{1}$ Creer, K. M., Miller, J. A., and Smith, A. G., Nature, 207, (1965)

2 Amaral, G., Gordani, U. G., Kawashita, K., and Reynolds, J. H., Geochim. cosmochim. Acta, 30, (1966).

${ }^{3}$ McDougall, I., and Ruegg, N. R., Geochim. cosmochim. Acta, $30,(1966)$.

4 Saito, T., Ewing, M., and Burckle, L. H., Science, 151, (1966)

5 Siedner, G., and Miller, J. A., Earth planet. Sci. Lett., 4, (1968)

${ }^{6}$ Maxwell, A. E., Von Herzen, R. P., Hsü, K, H. Andrews,
J. E., Saito, T., Percival, S. E., Milow, jun, E. D., and Boyce, R. E., Science, 168, (1970)

7 Le Pichon, X., and Hayes, D. E., J. geophys. Res., 76, (1971) ${ }^{8}$ Francheteau, J., and Le Pichon, X., Bull. Am. Ass. Petrol. Geo., 56, (1972).

a Wilson, J.'T., Nature, 207, (1965).

10 Dietz, R. S., and Holden, J. C., J. geophys. Res., 75, (1970) 11 Morgan, W. J., Nature, 230, (1971).

12 Morgan, W. J., Mem. geol. Soc. Am., 132, (1972).

${ }^{13}$ Ladd, J. W., Dickson, G. O., and Pitman, W. C., in The age of the South Atlantic (Nairn and Stehli, New York, 1973).

14 Sclater, J. G., and McKenzie, D. P., Bull. geol. Soc. Am., 84, (1973)

15 Goslin, J., Mascle, J., Sibuet, J. C., and Hoskins, H., Bull. geol. Soc. Am. (in the press).

${ }_{16}$ Freinex, S. in Sedimentary basins of the African coasts (Association of African Geological Surveys, 1966)

17 Noël, D., Coccolithes crétacés, Centre National de la Recherhe Scientifique, Paris (1970).

18 Brognon, G., and Verrier, G., in Sedimentary basins of the African coasts, (Association of African Geological Surveys, 1966).

19 Fox, P. J., Heezen, B. C., and Johnson, G. L., Science, 170, (1970).

20 Sclater, J. G., and Francheteau, J., Geophys. J. R. astr. Soc., 20, (1970). 